Viso - Cadernos de estética aplicada Revista eletrônica de estética

ISSN 1981-4062

No 24, jan-jun/2019

http://www.revistaviso.com.br/
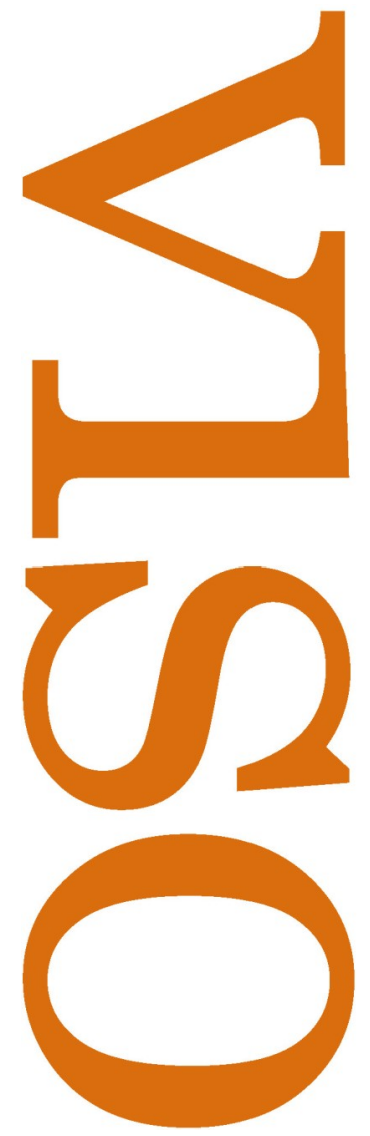

\title{
Narcisismo e autocrítica em Vergonha, do Coletivo Bruto (Antiteatrodocumentário 2)
}

Artur Kon 


\section{RESUMO}

Narcisismo e autocrítica em Vergonha, do Coletivo Bruto (Antiteatrodocumentário 2)

O ensaio busca descrever, analisar e interpretar Vergonha, obra teatral encenada pelo Coletivo Bruto em Piracicaba em outubro de 2016. Com isso, visamos refletir sobre as potencialidades de expandir o teatro documentário para além de sua forma mais habitual, exibicionista, individualista e melodramática, devolvendo ao teatro sua força não de ser real, mas de enfrentar um Real além da mera realidade, para melhor pensar o seu tempo.

Palavras-chave: teatro contemporâneo - estética e política - teatro brasileiro - teatro documentário

\section{ABSTRACT}

Narcisism and self-criticism in Coletivo Bruto's Shame (Antidocumentarytheatre 2)

This essay intends to describe, analyse and interpret Shame, a theatrical work staged by Coletivo Bruto in October 2016 in Piracicaba (Brazil), in order to consider the possibilities of expanding documentary theatre beyond its most usual, exhibitionistic, individualistic and melodramatic form, returning to theatre its power not of being real, but of confronting a Real beyond mere reality, in order to better think its time.

Keywords: contemporary theatre - aesthetics and politics - Brazilian theatre documentary theatre 
KON, A. "Narcisismo e autocrítica em Vergonha, do Coletivo Bruto (Antiteatrodocumentário 2)". In: Viso: Cadernos de estética aplicada, v. XII, n. 24 (jan-jun/2019), pp. 66-87.

DOI: 10.22409/1981-4062/v24i/312

Aprovado: 05.08.2018. Publicado: 30.06.2019.

(C) 2019 Artur Kon. Esse documento é distribuído nos termos da licença Creative Commons Atribuição-NãoComercial 4.0 Internacional (CC-BY-NC), que permite, exceto para fins comerciais, copiar e redistribuir o material em qualquer formato ou meio, bem como remixá-lo, transformá-lo ou criar a partir dele, desde que seja dado o devido crédito e indicada a licença sob a qual ele foi originalmente publicado.

Licença: http://creativecommons.org/licenses/by-nc/4.0/deed.pt_BR

Accepted: 05.08.2018. Published: 30.06.2019.

(C) 2019 Artur Kon. This document is distributed under the terms of a Creative Commons Attribution-NonCommercial 4.0 International license (CC-BY-NC) which allows, except for commercial purposes, to copy and redistribute the material in any medium or format and to remix, transform, and build upon the material, provided the original work is properly cited and states its license.

License: http://creativecommons.org/licenses/by-nc/4.0/ 
... trata-se sempre de mostrar ao espectador o que ele não sabe ver e de the envergonhar por aquilo que ele não quer ver. Jacques Rancière

Partamos antes de mais nada do seguinte - a palhaçada já está ali. Talvez colocando um pouco de vergonha no tempero, quem sabe, isso poderia contê-la.

Jacques Lacan

Talvez daqui a alguns anos, quando se puder olhar para o momento atual com algum distanciamento histórico, o ano de 2016 possa ser descrito como aquele em que uma nova geração (a deste autor) descobria - com uma surpresa talvez um tanto patética, uma desilusão um tanto farsesca - uma frustração que no entanto talvez já fosse velha conhecida de diversas tentativas históricas por parte de partidos ou grupos de esquerda. Sim, outro mundo é possível, temos evidências disso, colhidas inclusive ao longo de toda a primeira metade da década, desde a Primavera Árabe, os movimentos Occupy, os Indignados espanhóis, até o 2013 brasileiro: coisas acontecem, a história não é um presente contínuo e imutável, e nem chegou ao fim (ao "pós"), revoltas contra o passado e experiências de futuro surgem quando menos se espera. $E$, no entanto, não sabemos o que fazer com elas, além de assistir paralisados como são cooptadas, deformadas, transformadas em seu inverso. A pergunta central, que reemerge dessa decepção, parece ser: por que as maiorias silenciam em detrimento de seus próprios interesses (ou, pior, agem deliberadamente contra eles)?

Essa questão remete a certa fantasia narcísica da esquerda, a qual estaria por trás (ao menos segundo o filósofo Jacques Rancière) de certa visão muito difundida sobre o que seria ideologia. Trata-se da ideia de que o povo (sobretudo o "pobre de direita", figura frequentemente ridicularizada em tempos de militância nas redes sociais) é não apenas ignorante, mas necessariamente estúpido, graças à violência simbólica exercida sobre ele pela ideologia dominante que busca mantê-lo no seu lugar inferior: "A sociologia do 'não reconhecimento', a teoria do 'espetáculo' e as diferentes formas assumidas pela crítica das sociedades do consumo e da comunicação todas compartilham [...] a ideia de que os dominados são dominados porque ignorantes das leis da dominação". ${ }^{1}$ Ele deve, portanto, ser instruído pelo militante ou intelectual.

Essa ideia resulta, porém, no inverso do que pretende: não liberta o sujeito, antes reforça seu lugar de submissão: "Eis a virtude dos explicadores: o ser que inferiorizaram, eles o amarram pelo mais sólido dos laços ao país do embrutecimento: a consciência de sua superioridade". ${ }^{2}$ Esse discurso do mestre só reforça uma hierarquia entre ele e o suposto aluno: a dominação é propagada pelos discursos que pretenderiam criticá-la, ao pressuporem que ela funciona graças a um mecanismo de dissimulação que esconde suas leis daqueles que a ela estão sujeitos, apresentando a eles uma imagem invertida da realidade, mantendo-os na ignorância da sua própria alienação - cegueira cuja única cura estaria em aprender com os estudiosos que, esses sim, conhecem os mecanismos 
da ideologia dominante. Pode-se ler todo o projeto filosófico ranciereano como uma tentativa de demolir essa divisão entre os que sabem e os ignorantes, os aptos à atividade e os prisioneiros da passividade, entendendo por verdadeiramente político justamente o trabalho pelo qual os próprios "sem-parte" se fazem ouvir, colocando em questão a atual distribuição dos sujeitos entre audíveis e inaudíveis, visíveis e invisíveis (chamada pelo filósofo de "partilha do sensível").

Como seria possível transpor essa lógica para a produção teatral, criando uma cena que seja política sem ser policial (adjetivo empregado por Rancière para falar da lógica de manutenção da ordem normalmente considerada como "a política")? Uma opção talvez seria chamar ao palco aqueles que habitualmente estão excluídos dele, deixá-los falar por conta própria, permitir que eles se mostrem, se façam visíveis. É nesse sentido que "por volta de 2000 uma série de grupos, especialmente na Alemanha, tornou-se interessada em apelar ao público não só para estar ciente de corpos reais no palco, mas também de indivíduos reais do mundo real fora do palco", como analisa Marvin Carlson, citando o coletivo Rimini Protokoll como representante maior dessa tendência. ${ }^{3}$ É interessante notar que, se "nenhum dos performers das produções da Rimini Protokoll são atores profissionais", ainda assim "o grupo evita o uso da palavra 'amador", preferindo a ela o termo "especialistas do cotidiano", uma vez que "no palco eles apresentam o material de sua área de atuação, que é a sua própria experiência de vida". ${ }^{4}$ O sucesso do grupo teria dado origem a "uma nova onda alemã de uso de pessoas trazidas do mundo real", de modo que "muitos dos principais novos grupos experimentais do novo século [Carlson cita o She She Pop e o Gob Squad, além do coreógrafo francês Jérôme Bel] experimentaram tais materiais". ${ }^{5}$

Para a professora Sílvia Fernandes ${ }^{6}$, nesse tipo de experiência de "inclusão dos excluídos", "não atores" e "não cidadãos" (ela cita os casos paulistanos da Cia São Jorge de Variedades e da Cia Teatral Ueinzz), "o impulso de captura do real leva os criadores a confrontar o espectador com as coisas em estado bruto", de modo a fazer pingar "a última gota de desarranjo nos paradigmas da representação". ${ }^{7}$ Seria "evidente", segundo a pesquisadora, que a presença desses corpos "coloca em causa a representação, na medida em que interfere na cena com presença extracênica, que se apresenta mais como sintoma que como símbolo". ${ }^{8}$ A pesquisadora Julia Guimarães Mendes concorda com sua orientadora, acreditando que

a estratégia de fazer, no coração da linguagem cênica, emergir realidades de acordo com o ponto de vista daqueles que são compreendidos em seus contextos não só favorece uma ruptura com a tradicional indiferença em relação ao Outro que perpassa as sociedades urbanas contemporâneas como também tem o potencial de acessar a dimensão de alteridade presente em cada um, a ponto de tornar estranhas e questionáveis imagens cristalizadas que tradicionalmente construímos do mundo. ${ }^{9}$

Neste ensaio, gostaríamos de defender a hipótese de que há nessa ideia um equívoco fundamental, talvez certa ingenuidade romântica, a partir da análise de uma obra que 
parece partir dela, apenas para superá-la e até mesmo criticá-la: a peça Vergonha, do Coletivo Bruto, com direção de Paulo Barcellos, apresentada em Piracicaba em outubro de 2016. ${ }^{10}$

\section{Primeiro ato}

$\mathrm{Na}$ esquerda tradicional tal como criticada por Rancière, os mestres seriam críticos, conscientes, mas por isso mesmo tanto mais incompreendidos por um mundo de estúpidos: essa visão de uma missão dos intelectuais de levar a consciência de classe aos explorados "eventualmente [...] se dissolve em um puro pensamento de ressentimento que declara a inabilidade dos ignorantes de serem curados de suas ilusões, e portanto uma inabilidade das massas de se encarregarem de seu próprio destino". ${ }^{11}$ O sentimento de superioridade do mestre é complementado e reforçado por um sentimento de deslocamento. Talvez seja disso que fale a figura representada pela atriz Maria Tendlau, abrindo a peça:

MARIA: Eu sempre estive no lugar errado. Não. Eu estava lá, mas lá era o lugar errado. Tsc. Eu sempre tava errada no lugar. Não. Eu estava fora do lugar. Eu estava de fora, do lugar. Não, eu estou aqui e tá tudo errado. Que bela bosta! Eu estou me esforçando. Eu vou começar de novo. Cine Havaí, 1978. Meu pai me leva ao cinema para ver um filme da Disney [...]. Chegamos no cinema e antes de começar o filme, na tela enorme, filme bitola $70 \mathrm{~mm}$, um filme moderno, [...] uma reportagem sobre os avanços da indústria alimentícia brasileira. Na tela uma imagem gigante de carne, de bois pendurados numa esteira mecânica com ganchos. Tudo muito limpo. As pessoas de branco, muito higiênico. O futuro tinha chegado. Eu parei entre a luz da rua e a escuridão da sala iluminada pelo progresso em série na tela, com a imagem de desfile de carnes de boi penduradas e uma música muito alta. (Pára.) Tive um ataque de pânico. Comecei a chorar aos berros. Meu pai teve que me levar para casa e eu não vi o filme. Acho que foi lá que eu entendi que eu não tinha lugar naquela imagem. Não era boi, mas também não era boca, que come o boi. Ou era boi e boca, mas era olho também. Eu via aquilo tudo acontecer, de fora. Bom, desde então, pra esconder este terrivel segredo, eu aprendi a me camuflar para tentar sobreviver ao terror. Estar lá e não estar também. Perceber e passar desapercebida. Camuflagem. Essa peça também tem uma História que aos poucos será escondida e passará desapercebida. ${ }^{12}$

Ao longo de toda a peça serão projetadas periodicamente imagens de um abate de boi, desde sua chegada ao matadouro até a forma final dos cortes de carne, remetendo à história e ao contexto rural. Sobre essa fala, a atriz observa em um artigo recente ${ }^{13}$, já colocando em xeque a fronteira entre ficção teatral e depoimento pessoal: "Obviamente é um preâmbulo confessional, sobre minha própria posição na cidade como estrangeira". ${ }^{14}$ Pode ser interessante retomar seu breve panorama do histórico do grupo:

O Coletivo Bruto surgiu, em 2007, pela reunião de artistas de diferentes e múltiplas formações com o interesse de formar um grupo de criação que trabalhasse pelo hibridismo e pelo diálogo entre linguagens, na composição de obras artísticas. O objetivo [...] era dedicar-se à criação de matérias poéticas em diálogo com demandas contemporâneas, utilizando certa perversidade de imagens e discursos. Visavam à pre- 
sença das estereotipias e dos fetiches nas aglomerações urbanas, assim como refletir sobre os entraves da representação, na busca de um entendimento mais amplo das dinâmicas que sustentam a vida coletiva e a sobrevivência. ${ }^{15}$

Em 2013, eu, junto com Paulo Barcellos (deste momento em diante, o núcleo duro do Coletivo Bruto), me mudo de São Paulo para assumir um cargo de orientadora de Artes Dramáticas do Teatro da USP [...] em um campus do interior do estado de São Paulo. $\mathrm{Na}$ cidade em que moro, depois de um choque de realidade, ao sair de um centro absolutamente cosmopolita, me deparo com uma realidade muito mais delineada em sua herança oligárquica e de uma grande fragilidade no que diz respeito ao acesso à arte contemporânea [...]. Minha dificuldade de diálogo com a produção teatral local é patente. Trabalho, há dois anos, com um núcleo de poucos alunos tentando tornar concreta alguma produção. O esforço é vão. Foi preciso rever minhas estratégias. ${ }^{16}$

Vergonha parte daí, sendo resultado, segundo o programinha da peça, de um "segundo momento de uma pesquisa do coletivo [...] acerca da formação histórica do interior paulista e a ideologia que auxilia na manutenção das relações sócio-econômicas estabelecidas, forjada na imagem do progresso, embora conservadora". Essa "contradição aparente" entre ideologia do progresso e conservadorismo seria causa da "recorrência de um 'fora de lugar' vivido pelas figuras". A peça deveria denunciar uma "ideologia dominante desde a época da ditadura civil-militar", que resultaria numa "temporalidade deslizante em que toda ideia de futuro opera para imobilizar um presente que vive do passado", espécie de "sonho construído via discurso político-publicitário", cuja perpetuação depende dos "valores segregadores do passado presentificado decência, tradição e consumo". Assim, o interior paulista torna-se laboratório para a compreensão da situação política nacional (e talvez até mesmo mundial), à medida que "a oportunidade de estar deslocado do centro, estar na gigantesca maioria margem que alimenta o status quo deste país colônia eternamente em ordem e progresso, favorece um olhar para os conservadorismos nacionais mais arraigados - descendentes das monoculturas e das oligarquias patriarcais - que nunca serão de primeira classe".

Contudo, como já se vê na primeira fala de Maria, citada acima, não se trata apenas de expor uma problemática, um conteúdo, o que talvez pudesse ser feito lançando mão de certa linguagem cênica já desenvolvida e tecnicamente dominada, quem sabe a de um teatro épico à moda paulistana, ligado a uma leitura didatizante das propostas de Brecht (por exemplo aquela praticada há mais de duas décadas pela Cia do Latão, da qual Tendlau fez parte no início da trajetória do grupo), em que se criaria uma narrativamodelo que explicitasse a lógica sistêmica que insere as personagens num modo de funcionamento político e econômico específico. ${ }^{17}$ Vergonha parte, antes, da própria posição subjetiva dos artistas, isso é, de seus próprios impasses enquanto sujeitos politizados, pretensamente esclarecidos, potencialmente os "mestres" dos espectadores ignorantes, mas que sabem da insustentabilidade dessa posição, isso é, a peça parte da própria dificuldade de se falar disso com a gramática já existente, e portanto da necessidade de se criar novas formas para poder investigar os impasses da política brasileira sem recair num discurso dominador. Talvez por isso a primeira fala de Tendlau 
(citada acima) acabe indicando que a história da peça será "escondida" aos poucos, e não, como se poderia esperar, revelada; obscurecida e não esclarecida, questionada e não ensinada. Para observar esse curioso movimento, é preciso seguirmos a peça desde seu início.

Estamos diante de um cenário tosco, propositalmente pobre: todo o chão do espaço de apresentação, bem como um painel ao fundo, estão cobertos por papel pardo; num canto, uma cadeira de praia e um guarda-sol sugerem uma ambientação oposta ao interior paulista que se busca investigar. Tendlau está deitada na cadeira, dormindo, movendo-se e murmurando como se estivesse tendo um pesadelo. Ao fundo, são projetadas imagens da época da Ditadura Militar, enquanto ouvimos uma versão brasileira da famosa canção "Além do arco-íris", do filme O mágico de Oz. Logo que ela acorda com um grito de susto, entram os outros três atores fazendo uma grande algazarra, como "caipiras" chegando na praia e incomodando a atriz paulistana, que virá ao proscênio enunciar, num tom de atuação agressivo e quase forçado, seu primeiro discurso, acima citado. A diferença nos figurinos é explícita, e aos poucos perceberemos também diferenças na interpretação e até mesmo nos sotaques dos três em relação a Tendlau. A atriz tem datas escritas a caneta em sua placa; depois de terminar o primeiro texto, vai ao microfone e começa a lê-las, começando por 1964, justapondo acontecimentos da história do país e de sua trajetória pessoal (desde a de seus pais antes do seu nascimento):

1964 - Golpe Civil Militar. Os movimentos de cultura popular e as ligas campesinas são imediatamente dissolvidos. 1965 - Estreia "Repulsa ao sexo" do Polanski. Pela primeira vez o pico da neblina, ponto mais alto do Brasil, é escalado. 1966 - Dai deu pra sacar que a democracia tinha acabado mesmo. 1967 - Meus pais se casam. Meu pai larga minha mãe sozinha na festa de casamento. 1968 - Greve geral na França. Surge o cinema militante e rola a Internacional Situacionista. Muito legal. Aqui Al 5. 1969 - O homem chegou na lua. 1970 - Nasce a minha irmã. Luta armada. 1971 - Caetano volta a morar na Bahia. Matam Carlos Lamarca. 1972 - Nasce eu. Nasce a operação condor. Aquele lance de jogar gente no mar de um helicóptero.

Os outros atores também dão seus depoimentos pessoais, e de novo as diferenças em relação à atriz paulistana ficam escancaradas. O programinha já anunciava o uso de relatos reais como matéria prima: "as personagens, se é que podemos chamá-las assim, são fusões a frio dos atores, suas histórias e um retrato ácido cultural e social". Ou seja, para refletir acerca da atual realidade política brasileira, o Coletivo Bruto escolheu partir do teatro documentário, forma bastante usada na produção teatral contemporânea à medida que busca afastar a representação dramática tradicional e se acercar do campo da realidade.$^{18}$ Essa forma Ihes pareceu, ademais, um modo de lidar com a dificuldade de diálogo com o contexto piracicabano, comentada por Tendlau acima: "um trabalho com princípios de teatro documental [...] poderia ser uma ponte de comunicação com os artistas locais", além de contribuir "para a revisão de um lugar assumido pelos artistas locais", lugar descrito por ela como "um tanto caricato" ao representar "a figura fictícia do "caipira", ou então, na busca de certa profissionalização, "importando modelos 
desvinculados de seus processos geradores - característica de um teatro amador que tenta repor o teatro profissional sem o seu lastro". ${ }^{19}$

Ora, para que a comunicação almejada não fosse superficial, precisava assumir os conflitos e contrastes, as contradições e as tensões, e não pressupor uma situação simétrica de fala. Donde a ênfase nas diferenças, realçadas de modo quase caricatural (mas não no sentido do "caipira" criticado no comentário de Tendlau, mais uma tipificação idealizada, ingênua, do que o desenho intencionalmente grosseiro, com potência crítica, que vemos aqui). Por outro lado, busca-se explicitar um ponto-de-vista específico sobre essa diferença, já que os paulistanos do Coletivo Bruto são responsáveis pela direção e dramaturgia da peça, enquanto os piracicabanos ocupam "apenas" a posição de ator (em geral vista como hierarquicamente "inferior" à do diretor e do autor). Essa distinção se torna material cênico: "Durante todo o primeiro ato, fica claro que eu comando a peça. Eu mando nos outros atores, faço comentários, dialogo com os vídeos. Eu não me comovo com as narrativas. Eu mando os demais terem coragem de se expor". ${ }^{20}$ Com essa hierarquização explícita e assumida, a distinção entre atores e "não atores", tão explorada pelos chamados "teatros do real", é de certo modo reproduzida ou representada dentro da peça: mesmo que os atores interioranos também sejam profissionais, são colocados na posição de amadores, ou melhor dizendo de "especialistas da vida rural", isso é, da vida real. O que nos lembra que essa distinção entre profissionais e amadores não é natural ou ontológica, mas relativa e construída pela própria representação.

A intensificação dos traços contamina também a enunciação dos textos, conforme os atores começam a brigar para decidir quem terá espaço para contar sua história. É um documentário tornado histeria, tomado pelo narcisismo das histórias pessoais - o que nos obriga a notar a cumplicidade entre, por um lado, o interesse do teatro contemporâneo (ou de certa teoria sobre ele) pelo campo do pretensamente "real" e, por outro, a fetichização ou espetacularização das vidas privadas no capitalismo tardio, manifesta em reality shows e redes sociais da internet. Contrapondo esse narcisismo ao próprio título do trabalho, podemos pensar no exibicionismo como problema maior a ser tratado num teatro que parte do documentário para ir além dele. ${ }^{21}$ Vale lembrar a observação do filósofo Slavoj Žižek, refletindo justamente sobre a vergonha: "Hoje, a ansiedade advém da perspectiva de não ser exposto ao olhar do Outro o tempo todo, de modo que o sujeito precisa do olhar da câmera [ou de uma plateia de teatro] como um tipo de garantia ontológica de seu ser". ${ }^{22}$ Assim, se Tendlau (ver adiante) falará sobre a teatralidade da vida social externa ao teatro, Žižek vê "a mais elementar teatralidade da condição humana" no fato de que "o nosso anseio fundamental não é por observar, mas por ser parte de uma cena encenada [a staged scene], por se expor a um olhar - não o olhar determinado de uma pessoa na realidade, mas do Olhar puro inexistente do grande Outro" ${ }^{23}$ Por isso mesmo, não é a posição do ator que é a mais difícil, insuportável, "impossível" mesmo, dirá o filósofo, mas a do espectador, a do público. ${ }^{24} \mathrm{O}$ que nos permite lembrar como, para diversos pensadores (como Adorno e o próprio Rancière), 
ser espectador de uma obra de arte significa entre outras coisas estar exposto ao olhar (sem olhos) da obra, como descrevia Rilke o acéfalo "Torso Arcaico de Apolo": "Pois ali ponto não há que não te mire". ${ }^{25}$

É preciso considerar as consequências dessa inversão (em relação ao senso comum que crê que se expor no palco é a causa maior do sentimento de vergonha) para uma linguagem como a do teatro documentário, que parte da exposição de "histórias verdadeiras de pessoas reais". Pois não há subjetivação possível, não há verdade ou Real, quando o fetiche da "vida real" se transforma numa competição para ver quem consegue vender melhor sua história, ou seja, quem melhor consegue transformar sua narrativa de si mesmo em mercadoria, adequando-a ao gosto do comprador - gosto normalmente dominado pelo melodramático da teledramaturgia ou de Hollywood, que tem na identificação emocional com um protagonista individual sua pedra fundamental, em detrimento de qualquer consideração que leve em conta o plano transindividual ou sistêmico. Podemos lembrar, nesse sentido, como o trabalho político de contar a "parte dos sem-parte" não pode ser uma mera representação de sujeitos excluídos feita em moldes tradicionais. Até porque a parte dos sem-parte em Rancière não é simplesmente excluída, não é um outro radical que estaria "fora" da atual configuração da sociedade: ele faz parte justamente não tendo parte, sendo incluído como "excluído", ou sendo visível somente em uma moldura de visibilidade já dada. O exibicionismo do real presente em boa parte da produção que se vale da linguagem do documentário (por exemplo, a daqueles grupos citados no início deste ensaio) perpetua essa lógica, ao invés de criar uma verdadeira "repartilha do sensível". ${ }^{26}$ Nesse sentido, a oposição entre as histórias de infância dos atores de Piracicaba e as de Tendlau também indicam que essa fetichização da memória (pessoal) pode ter como contraparte ideológica um perigoso apagamento da história (coletiva), por exemplo. Por um lado, as narrativas da paulistana revelam sempre uma consciência da relação entre vida e contexto social, formação cultural (ela cita artistas, escritores e espaços culturais conhecidos e frequentados pelos seus pais); por outro, sua politização explícita ameaça ocultar o interesse social que também os outros depoimentos apresentam, revelando em situações concretas estruturas arraigadas de dominação patriarcal e capitalista:

Os relatos são íntimos e, na maioria das vezes, muito violentos. Vão desde a história da mãe que foi vendida para uma família de fazendeiros para trabalhar de graça e acabou se casando com um dos filhos da família que a estuprou (um dos atores é filho dessa união), até a falta de comida ou a violência doméstica; o abandono pelo pai que viu a própria mãe ser atingida por uma bomba na Itália, na segunda Guerra Mundial; o analfabetismo da mãe nordestina etc. As histórias são todas muito violentas, mas são contadas com bastante delicadeza. Em contraponto, minha personagem relata também histórias de infância, mas sempre com um recorte claramente histórico e engajado. ${ }^{27}$

Interessa notar como ao narcisismo das narrativas íntimas se opõe uma vergonha (para remeter novamente ao título do espetáculo) em relação à história política brasileira. Trata-se de uma relativa inversão de expectativa, sendo o privado habitualmente o 
campo do acanhamento e do embaraço, e o público o domínio da exposição (quando não o orgulho ufanista, como pretendiam os militares cuja imagem povoa a peça, aparecendo periodicamente em vídeos projetados de seus discursos), como fica patente nos dois últimos depoimentos, feitos pelos atores homens, que tratam (de modo desavergonhado) da vergonha da pobreza na infância (vergonha da própria casa pobre, da mãe analfabeta).

Em meio a toda essa exposição, há diálogo entre as duas atrizes, a paulistana Tendlau e a piracicabana Carla Sapuppo, que vêm para a frente do palco enquanto os homens ao fundo "iniciam um jogo em que arremessam [num tipo de duelo] cartas de baralho com frases de ideologias de uma nova nação" (como "Deve ser Uma engrenagem / Um todo coerente / Não há sobras/ [...] É preciso apagar os vestígios/ A sujeira/ E criar um mundo novo/ Limpo/ Puro/ Um mundo moderno/ Capaz de gerir os negócios/ Mais trabalho para todo o tipo de gente/ Brancos Negros Pardos Estrangeiros Mulheres Crianças"). As duas conversam "muito intimamente sobre como sobreviver a um mundo masculino", ou ainda "sobre possibilidades de se transmutarem para sobreviver", como indica a rubrica, e surge uma ideia que será importante no desenvolver da peça: "MARIA - Podemos sumir. / CARLA - Vamos sumir? Agora?" Pela primeira vez sugere-se a possibilidade de negar ou superar o narcisismo dos indivíduos e seus depoimentos. No segundo ato, veremos Tendlau tentando desaparecer no meio do cenário, cobrindo-se de papel pardo, camuflando-se. No artista (como na violência do criminoso), dizem Adorno e Horkheimer ${ }^{28}$, está corroída "a energia necessária para se destacar como um indivíduo do mundo ambiente e, ao mesmo tempo, para estabelecer uma ligação com ele, através das formas de comunicação autorizadas, e assim nele se afirmar"; antes ele tende "a perder-se em vez de impor-se ativamente no meio ambiente, [tem uma] a propensão a se largar, a regredir à natureza. Freud denominou-a pulsão de morte, Caillois le mimétisme. Um vício semelhante atravessa tudo o que se opõe ao progresso inflexível".

\section{Segundo ato}

"O segundo ato muda completamente o registro até então dado. Uma mesa de ferro invade a cena, e uma copeira a prepara para [a] ceia [...]. A copeira é a única personagem ficcional da montagem. Ela é interpretada por uma bailarina-atriz que, até então, não havia aparecido em cena [...] O tom, dos demais, já de início é histriônico". ${ }^{29}$ Podemos estranhar cair nessa ficção depois de acompanharmos o primeiro ato "pósdramático" e documental. Mas a atriz afirma ser justamente esse o seu interesse: propiciar o confronto entre o espaço propriamente teatral da cena e uma certa teatralidade ("expandida") própria "às relações políticas e sociais em espaços diversos que ultrapassam a cena em si", isso é, o modo como as realidades que se supõem estar "fora" do teatro "são prenhes de teatralidade" ${ }^{30}$, como se vê por exemplo no histrionismo representado pelos atores nesse segundo ato. É "essa teatralidade [que] 'dá a volta do parafuso' e aparece novamente na cena fazendo as vezes do real". Ademais, devemos 
lembrar com Jacques Rancière que "a linha separando o documentário da fiç̧ão" é, na realidade, uma "distinção em gêneros que separa voluntariamente dois tipos de humanidade: aquela que sofre e aquela que age, aquela que é objeto e aquela que é sujeito" (ou ainda, no caso da experiência do Coletivo Bruto explorada na peça, os artistas engajados da capital e os caipiras ignorantes); de modo que só pode ser verdadeiramente crítica uma arte que embaralha essas "linhas de separação que configuram o campo consensual do dado". ${ }^{31}$

Os atores estão com outros figurinos, apontando uma certa transformação em relação ao primeiro ato: agora são figuras mais bem-vestidas, talvez representando menos o pobre "caipira" do que o "novo rico" do interior paulista (um como escoteiro, outro com terno, Carla com uma blusa brilhante e sacolas de compra), combinando com a situação de um jantar servido por uma copeira uniformizada. Já Tendlau aparece enrolada em papel pardo, como um vestido de festa improvisado, aparentemente nua por baixo. Ela pede a palavra como se quisesse pronunciar um discurso: "Eu gostaria de agradecer a recepção de vocês por me acolherem e por me permitirem fazer parte desse momento. Eu escrevi um pequeno poema para cada um de vocês como forma do meu agradecimento". Os poemas, num tom pretensamente elevado, desenham criticamente as figuras:

Eis um homem diante de sua altivez/ Eis um homem diante de sua pequenez/ Quase sem carnes, com seu horizonte exíguo/ Eis um homem que não precisa de muito/ Alegria e justeza apenas/ Mãe com pouco, pai com pedras/ Amor sempre igual, justo, nos conforma/ Eis um homem diante de sua pequenez

Eis uma mulher diante de sua força/ Quanto suporta? Suporta tantos./ Não pára. Por que não pára?/ Eis uma mulher diante de sua força

Eis um homem diante de sua persistência/ Depois de reprimido/ Em seus dons mais generosos/ $\mathrm{Na}$ herança maldita da pobreza/ Só um pouco de beleza afinal/ Eis um homem em sua persistência

Os três aplaudem, mas não parecem dar muita importância. Imediatamente retomam seus depoimentos, os mesmos que já apareceram no primeiro ato, mas agora enunciados na terceira pessoa, como uma conversa durante um jantar, sempre em voz muito alta, acompanhados de risos histéricos (rindo inclusive da pobreza presente nos relatos), repletos de preconceitos (um dos atores refere-se a si mesmo, na terceira pessoa, como "bichinha mulata"). A conversa gritada, histérica, só é interrompida quando entra a empregada para servir água, vinho, sopa, gerando um silêncio constrangido entre os comensais, sobrando apenas o tique-taque de um relógio de pêndulo como efeito sonoro; "como se certos assuntos não devessem ser conversados na frente dos empregados". ${ }^{32}$ Tendlau está deslocada, fora de lugar, claramente constrangida; "vai se chocando cada vez mais com os comentários racistas, preconceituosos e violentos dos demais" ${ }^{\prime 3}$, faz perguntas e observações (retoma depoimentos também, ainda em primeira pessoa, novamente marcando sua diferença em relação aos demais, como quando se refere ao feminismo avant la lettre de sua mãe). Mas seus comentários são sérios, 
mesmo se diz algo sem seriedade, como quando tenta entrar na brincadeira dos demais, sem sucesso: Jorge joga água em seu rosto, ao que todos riem, menos ela; Carla força-a a comer sopa. Nas palavras da própria atriz: "Fica patente a minha arrogância, o meu deslumbre intelectual e um tom de superioridade disfarçado por um olhar, inicialmente condescendente e 'inclusivo'. Os demais se rebelam contra minha arrogância, me interrompem, jogam água na minha cara, me ridicularizam". ${ }^{34}$

Depois de um tempo, a intrusa paulistana pára de silenciar quando a empregada entra, faz questão de reconhecer sua presença e tenta dialogar com ela, agradece-lhe pela comida e pela bebida. Ao mesmo tempo, faz questão de contar suas histórias em que faz referência constante a sua formação cultural diferente das dos demais, não sem explicitar também as contradições dessa posição social ao mesmo tempo privilegiada e socialmente consciente e engajada:

\begin{abstract}
Minha mãe tinha uma empregada doméstica e essa empregada gostava muito de ler e a minha mãe tinha muitos livros. Essa empregada pegava livros pra ler e ela pegou um livro que se chamava A Miséria da Filosofia. Como ela era muito depressiva a gente imagina que ela escolheu esse livro por causa da miséria e não pela filosofia. [...] E como ela era muito carente também, a empregada imaginava que era filha de minha mãe também, até que chegou num ponto insustentável que ela que teve que demitir a empregada. Foi triste. Anos depois, a minha irmã foi numa feira de rua que tinha a Monga, a Mulher Macaco. Ela assistiu e quando terminou saiu branca lá de dentro e todos ficaram preocupados e perguntamos o que havia acontecido. A Ju, minha irmã, disse que ela, a empregada, era a Monga. Essa cientista foi fazer uma pesquisa numa floresta tropical e algo estranho aconteceu com ela. Vejam só: pele, carne, cabelo, cabelo, pele e carne. Nunca soube se a empregada era Monga e fazia bico de empregada doméstica ou se era empregada doméstica e fazia bico de Monga.
\end{abstract}

A próxima a falar é Carla: "Na sala de jantar no pensionato (começa a enviar sopa na boca da Maria) da avó dela tinha muitos homens. E ela tinha que servir. [...] Enquanto isso o tio dela tocava violão numa nota só e cantava 'Índia seu Cabelos"'. No meio desse depoimento, entra a copeira para servir mais sopa. Indignada com esse suposto desrespeito, a atriz interrompe sua fala, joga suas sacolas de compras no chão, sobe na cadeira e grita com a empregada: "Só entre quando for chamada. Muda essa cara. Quem nasceu pra servir mesa vai ficar a vida inteira servindo mesa. Saia! Saia!" Quando a outra sai, Carla começa a cantar com grande alegria a música citada em seu relato, como se nada tivesse acontecido. Todos riem, Tendlau cobre o rosto com o papel pardo, dando continuidade a sua tentativa de desaparecer camuflando-se no cenário, e grita mais um depoimento, no qual fala sobre "o Ernesto", seu primeiro amor, filho de um casal cubano exilado, circunstância perfeita para sua idealização de militante de esquerda: "o Ernesto tinha vida, ele tinha brilho no olho, porque em Cuba as pessoas têm dente, as pessoas têm sangue, as pessoas têm sensualidade". Enquanto isso todos conversam.

De repente entra a empregada com uma máscara de gorila - em referência à "Monga" da história de Tendlau - e xinga ao microfone os três piracicabanos: "machista 
conservador patético", "submissa machista infantilóide chorona sonsa mão de vaca", "limpinho educadinho homofóbico limitado boçal misógino". A protagonista paulistana ri e aplaude, contente com a insurreição da trabalhadora oprimida, mas a empregada lhe diz: "E você, não se meta, caralho!". Quando ela sai, todos riem, menos Maria, que se senta na mesa de costas para o público, humilhada. As narrativas dos demais continuam. Ao fundo, é projetado um letreiro: "enquanto o futuro não chegava, todo ano o governo militar lançava uma campanha com mensagens positivas de paz e confraternização", ao que se segue o vídeo de uma dessas propagandas. Legendas contêm uma descrição literal de tudo o que se passa na tela, explicitando o ridículo: "um casal corre feliz no campo, eles estão livres, muito felizes; de repente um musicista clássico aparece e todos se encontram por coincidência e dirigem um carro antigo em direção ao sol"; "uns ricaços da cidade se misturam com os bois"; "o sol e o pássaro trazem uma mensagem de esperança, e todos felizes se encontram em volta de uma fogueira"; "agora a loirinha dança com o senhor negro que provavelmente trabalhava na fazenda onde foi realizado o job e que nem precisaram pagar cachê; e termina com uma mensagem final positiva de que todos são iguais, debaixo da mesma árvore da vida".

Tendlau, que estava de costas, e portanto assistia ao vídeo todo, arranca revoltada o papel pardo do corpo, ficando nua. Ela pega um microfone e diz o texto final da peça:

Deitada em uma cadeira de praia, vejo projetada na parede desenhos de contos de fada medievais. Penso sobre o orgulho e a legitimação do meu lugar no mundo, um pouco acima dos demais, mas nem tanto. Quem está por baixo, pelo menos está livre de cair, diz o ditado. Mas também diz: Modéstia em excesso não deixa de ser meia vaidade. Reflito se a ausência de punição a um crime é na verdade um perdão. Um crime sem motivo, um crime não punido. Se eu não vou ser punida por minha arrogância de estar acima dos outros - elevada, classe alta, branca, olhos azuis, ascendência europeia, intelectual - por que, me diz, por que eu me esforço por parecer humilde, por me irmanar com os desgraçados? Por quê? Que arrogância conceitual me impele a achar que a injustiça social deve ser corrigida. [...] Por que quando havia alguém torto, tonto, deslocado na escola, era comigo que ele se identificava? E era só eu que não tinha cara de dizer: Sai daqui! Eu não quero ser torta, tonta ou deslocada! Eu da classe médiaelite-europa-cultura-refinamento deitada em berço esplêndido quero ainda por cima ser SANTA ou ainda: não suportaria a falta de classe de rejeitar alguém. [...] $E$ eu, eu estranhona, panicada, meio eu não gosto de ninguém, e todos tão bobos e chatos e coniventes com as injustiças. Gente burra, que fala do passado como se fosse bom, gente que nunca plantou uma alface, que não tem esse conhecimento. ${ }^{35}$

A fala vai adquirindo um tom violento, quase panfletário, sendo gritada pela atriz ao microfone, de modo bastante agressivo:

[Gente] que só repete o que o dono fala. E o dono também não pensa, mas tem dinheiro e paga pros outros pensarem por ele. E imagina o pânico de ir jantar na casa dos colegas de escola, gente de bem, com duralex, com sobremesa, com mãe em casa cozinhando, com decência e fervor civil. EU TINHA MEDO!!!!!!!!!!! (Ela grita [é o que diz o texto, mas na encenação ela na verdade pede baixinho, com vergonha da própria nudez, se cobrindo com as mãos] com os outros atores de cima da mesa) Agora chega. Chega de vocês! Sai! Sai agora. Eu tô mandando. (para o público) Agora vocês... Vocês. 
Vocês podem aplaudir. Acabou. É o fim. Façam alguma coisa. Aplaudam. Querem uma musiquinha pro final? [para de tentar se cobrir e grita:] Põe a porra da musiquinha pro final. (MARIA agradece e a luz abaixa)

A própria atriz descreve essa cena do seguinte modo: "numa atitude autoritária, expulso os três outros atores para finalizar a peça e receber os aplausos sozinha", após o que "a plateia fica num silêncio constrangido. Minutos de uma sensação de total desestabilidade. Às vezes, um espectador pergunta para o outro: É pra aplaudir? O que faço agora?". ${ }^{36}$ Há um vídeo final, em que aparece um gramado com vacas pastando. Quando a atriz sai de cena, surge no vídeo, ainda nua. Ela corre pelo pasto, diante das vacas, e dá bananas para o público. Como se assumisse a posição de artista engajada superior, arrogante, que deve enfrentar o público passivo e ignorante, chocá-lo para ensinar-lhe algo, fazê-lo sentir vergonha. No entanto, ao assumir esse papel, ele se torna justamente isso: um papel teatral, ou seja, uma construção ficcional feita para ser assistida com distância crítica. Como a própria atriz indica em seu artigo, há um forte aspecto metateatral no espetáculo: Tendlau dirige e protagoniza a cena, é a esquerda culta, é a atriz de teatro político pós-Latão, sua história de família é totalmente diferente da dos outros - seu desajuste é real, mas sua solução é ajustada demais a tudo isso, ao seu lugar de intelectual crítica e superior. Se ao final a atriz ataca o público, aparentemente reproduzindo exatamente a postura criticada por Rancière em nossa epígrafe $^{37}$, o efeito é inverso: na realidade quem passa vergonha é a própria Tendlau.

Por outro lado, segundo ela, também para o espectador "a peça é absolutamente desagradável", uma vez que "o público reconhecia-se muito facilmente nas imagens, mas não conseguia permanecer em um ponto isento. Ninguém se salvava". ${ }^{38} \mathrm{O}$ que nos pede uma reflexão sobre o possível papel político do sentimento de vergonha hoje. Um possível ponto de partida é a reflexão encontrada no livro mais recente da escritora Marcia Tiburi, Ridículo político ${ }^{39}$, onde a autora procura versar sobre certa estética da política contemporânea (continuando sua reflexão de Como conversar com um fascista, sobre o Brasil atual e o emergente conservadorismo raivoso). Ali, Tiburi opõe vergonha e ridículo, entendendo que "o ridículo é um lugar no qual nos pomos pela falta de vergonha" (ela supõe, por exemplo, que "um personagem que demonstrasse sua vergonha escaparia do ridículo"), a qual por sua vez "constitui uma certa medida do olhar do outro, mas também uma medida do outro", já que "em geral, nos envergonhamos quando sentimos respeito por quem nos vê"..$^{40}$ Mas é fundamental enfatizar a dimensão política desses dois opostos, e sua atualidade, numa observação que remete imediatamente à oposição entre o reconhecimento da "parte dos sem-parte" na política ranciereana ${ }^{41}$ e o narcisismo das narrativas pessoais astutamente representado pelo "anti-teatro-documentário" do Coletivo Bruto. Para Tiburi,

em uma economia política da imagem, o ridículo seria o principal elemento de nossa época. Uma época na qual pessoas de todas as classes se interessam pela fama sem perceberem como ela é uma deturpação do reconhecimento. A fama é do campo do ridículo como estilo e como prática, mas, enquanto ela é desejada, o reconhecimento é 
preterido. No contexto da sociedade do espetáculo, o ridículo expressa sua relação com a fama na forma de cenas publicizadas em redes sociais. O ridículo chama a atenção e, por isso, é tratado pelos cidadãos em redes sociais, na internet, como um capital. ${ }^{42}$

Todo o segundo ato da peça, com a constrangedora cena da ceia, parece encenar perfeitamente "uma cultura em que a falação de merda é tratada como normal", como analisa a escritora, e onde "a ridicularização é cada vez menos percebida, a ponto de, quando percebida, não causar muitos problemas ou, no extremo, tornar-se até um capital". ${ }^{43}$ Ora, o Coletivo Bruto deixa explícito em sua encenação que não se deve relacionar esse ridículo apenas ao outro caipira, ignorante, caricaturado como fascista. A própria esquerda supostamente esclarecida, justamente nessa sua pretensão iluminista, é igualmente ridícula. Ou ainda mais ridícula, uma vez que é ela que, como Tendlau na peça, se sente deslocada, injustiçada, ofendida por aqueles que, por sua vez, estão talvez confortáveis em sua posição atual, sem motivos para se questionar ou envergonhar. O que nos remete a outra reflexão sobre a relação entre o sentimento de vergonha e a política que se quer revolucionária: aquela feita por Jacques Lacan após o maio de 1968 francês.

Segundo Jean Copjec, tratava-se de mostrar como, "embora os estudantes quisessem acreditar que estavam abandonando a universidade pelas ruas, a universidade não era abandonada tão facilmente", isso é, "ela já havia começado a ocupá-los - bem como às ruas". ${ }^{44}$ Com o gesto exibicionista (como no narcisismo de certo teatro documentário?) de "desfilar seu gozo dedicado para todos - especialmente o Estado - verem e gozarem"45, os estudantes acabariam submetendo-se aos modos disponíveis de gozar e ao uso controlado de seu próprio gozo. ${ }^{46}$ Ora, essa ideia de uma reprodução inconsciente de um discurso dominador (aquele chamado por Lacan de "universitário") no campo da luta política não parece próxima da descrição de Rancière dos intelectuais de esquerda? ${ }^{47}$ Lacan $^{48}$ insiste que os estudantes estão brandindo um "discurso do Mestre pervertido" que "é o discurso universitário", e que faz eles "não morrerem de vergonha" como seria de se esperar justamente "porque morrer de vergonha é, para o honesto, o impossível" o que, para Lacan, quer dizer "o real". ${ }^{49}$ Essa curiosa valorização da vergonha viria do pensamento de Sartre, para quem "a vergonha é, por natureza, reconhecimento", isso é, "reconheço que sou como o outro me vê" 50 ; trata-se do momento em que deixo de me considerar sujeito e passo a me reconhecer como objeto (do olhar do outro). ${ }^{51}$ Por que Lacan colocaria essa apreensão de si mesmo como um objeto como fundamental?

Podemos compreender essa necessidade remetendo ao diagnóstico do psicanalista Christian Dunker sobre "a ascensão de uma cultura participativa" em nosso tempo pós1968, cultura "na qual a exposição, a comparação e a confrontação de posições viram uma regra maior" e que "torna o compartilhamento de afetos uma espécie de valor moral", criando "dificuldades para aqueles para quem a privacidade é essencial". ${ }^{52} \mathrm{~A}$ possibilidade de falar em público, longe de ser reprimida, passa a ser estimulada "nas escolas, no mundo corporativo e nas situações sociais", na forma de "apresentações, 
seminários, aulas, intervenções e comentários", o que Dunker compreende como "uma exigência geral de uma forma de vida orientada pelo investimento na sociabilidade do contato múltiplo e permanente", mas também "uma nova forma de trabalho, mais compartilhada, flexível e com maior horizontalidade de processos decisórios" 53 (bem sabemos que essa horizontalidade não atinge os salários e direitos, e que flexibilidade costuma significar precarização). É essa mesma sociedade que cria os reality shows com sua tentação exibicionista e narcísica: "colocar pessoas reais para representar a si mesmas, dissolvendo o litoral entre espaço público e espaço privado, parece a brincadeira infantil de flagrar a intimidade dos adultos, ou então olhar pela fechadura da porta", comportamento que supõe uma relação imaginária de identificação e compensação: "a fórmula inicial de que para ser um ator basta ser você mesmo funciona como uma espécie de desculpa ou de consolo para nosso sentimento de que a vida é cada vez mais inautêntica, poseur ou fabricada". ${ }^{54}$ Para Lacan, apenas a vergonha seria capaz de combater "o mito do Eu ideal, do Eu que domina, do Eu pelo qual alguma coisa é pelo menos idêntica a si mesma" ou ainda a "Eu-cracia" que surge de todo "discurso universitário". ${ }^{55}$ É daí que se origina a necessidade de humilhar Tendlau em cena, de fazê-la passar vergonha, o imperativo do autolinchamento, a pulsão destrutiva de autocrítica ${ }^{56}$, um pouco como uma vítima sacrificial, talvez como uma das vacas que vemos ser abatidas nas projeções ao longo da peça, e entre as quais ela corre no vídeo final. "O objetivo final da psicanálise, no final das contas, é a produção de vergonha". ${ }^{57}$

E, no entanto, a autocrítica encenada pelos artistas paulistanos do Coletivo Bruto na cidade de interior não anula ou oblitera o impasse radical a que se chega com a pergunta: como lidar com o Outro que eu odeio? Não se trata, aqui, do Outro que me odeia, com quem eu poderia estabelecer um conflito dramático tradicional, a ser desenvolvido até o desenlace adequado com os meios técnicos de uma dramaturgia hegemônica; mas, antes, de um Outro que sequer consegue imaginar minha existência. Também não se trata do Outro que eu fantasio, representando-o de maneira idealizada como protagonista heroico em um teatro de esquerda tradicional (mas com o qual também não sei lidar por mais tempo do que os cinco minutos que nossas posições sociais normalmente prescrevem, e que diante da minha tentativa de defendê-lo ordena que eu não me meta, como a empregada-gorila da peça), mas um que eu desprezo totalmente. "Na cena, com toda a dificuldade que é se expor nesse nível, os atores se deixavam ser conduzidos e julgados pela minha pessoa, em suas deficiências, assim como deixavam claro que, sim, às vezes dá vontade de jogar água na minha arrogância de estrangeira". ${ }^{58} \mathrm{O}$ processo colaborativo, "sempre pactuado entre todos", não significou aqui "igualar as perspectivas de cada um", mas permitir que as diferenças viessem à tona sobre o palco: "a violência não se dissipa". ${ }^{59}$ Ao optar pela ficção em seu segundo ato, o Coletivo Bruto apresentava uma situação perfeitamente real, possivelmente vivenciada por muitos espectadores: a vergonha que o morador "esclarecido" e moderno da capital sente diante da sua própria família do interior, uma vez por ano, no temido jantar de Natal (no começo da cena, uma mensagem natalina do ex-presidente José Sarney indica que essa pode ser a ocasião da ficção). ${ }^{60}$ 
Essa identificação não é a do teatro dramático tradicional (frequentemente reproduzida por certo teatro documentário bastante reproduzido, e com isso reificado, verdadeiro melodrama disfarçado de contemporâneo $\left.{ }^{61}\right)$, não é catártica, emocionante, humanizante, mas desconfortável, desagradável, indesejada, que "subverte o pacto pacificador que envolveria a plateia e colocaria o espectador em um lugar seguro" à medida que "os atores se dispõem a posicionarem-se em suas faltas, mas não abrem mão de sua posição numa sociabilidade que já está dada fora da cena". ${ }^{62}$ Não é a identificação de um espectador com um sujeito autônomo, individual e pessoal que aparece em cena agindo, mas com um sujeito que se confunde com um objeto, que não sabe agir, que não está na posição de deliberar o curso de seu destino e muito menos os caminhos da sociedade ou de uma luta coletiva. Por vezes essa identificação é também (usando o diagnóstico de Tiburi) simples e abertamente ridícula: "A propaganda de final de ano desperta na plateia o canto: todos conhecem a letra, todos a consideram sua". ${ }^{63} \mathrm{~A}$ farsa da repetição histórica é explicitada nos vídeos: "As frases de Médici são repetidas por Sarney, por Collor, por Temer"; o Brasil que "está na cena [...] somos todos nós"; nós nos identificamos justamente naquilo que Tendlau descreve como "um enorme reacionarismo na forma de 'valores' [...] que não mudaram desde 1964”. Em nota de rodapé, Tendlau esclarece que "o governo Temer não aparece [explicitamente] na peça, mas está absolutamente presente do ponto de vista das formas iguais aos governos militares: ternos, homens, festas" ${ }^{64}$ É difícil não pensar que os vídeos projetados são uma terrível genealogia do atual momento político do país, a crônica de um golpe anunciado diante do qual somos obrigados a confessar que não sabemos o que fazer (abrindo mão da falsa confiança que os anos de Lulismo haviam gerado). Mas, como lembra Bernard Stiegler, diante da injustiça, "o que liga o nós político é desde logo, e sempre, o saber da sua fragilidade - o não saber que é a condição da desonra, aquilo que eu chamo vergonha". ${ }^{55} \mathrm{Sem}$ admitir que não temos ainda a solução para o impasse colocado em cena pelo Coletivo Bruto Lacan insistia na dessuposição do saber como momento fundamental no final de análise, à medida que só assumir o não-saber permitiria uma abertura para afrontar a verdade ${ }^{66}$ -, sem nos permitir essa vergonha, esse ridículo, provavelmente não conseguiremos abrir o espaço vazio para inventá-la.

\footnotetext{
* Artur Kon é doutorando em filosofia pela USP.

${ }^{1}$ RANCIERE, J. Althusser's lesson. Londres: Continuum, 2011, p. xvi.

2 Idem. O mestre ignorante: cinco lições sobre a emancipação intelectual. Belo Horizonte: Autêntica, 2002, p. 34.

${ }^{3}$ CARLSON, M. "Expansão do Teatro Moderno rumo à realidade". In: Art Research Journal Brasil, v. 3, n, 1 (jan-jun, 2016), p. 10. O público paulistano pôde conhecer o trabalho do Rimini Protokoll na terceira edição da Mostra Internacional de Teatro de São Paulo (MITsp), em 2016, em que foi apresentada a obra $100 \%$ São Paulo, que punha em cena cem não-atores paulistanos escolhidos de modo a refletir dados estatísticos a respeito da demografia da cidade, num elogio ingênuo e acriticamente "humanista" da diversidade.
} 
${ }^{4}$ Ibidem, pp. 10-11. Em São Paulo, o termo "amadores" foi não apenas aceito, mas até mesmo abraçado e alçado a título de espetáculo da Companhia Hiato, cuja exploração dos limites entre ficção e realidade em diversas peças é exemplar para a discussão dos "teatros do real" e do "teatro documentário" de que parte este artigo; em Amadores, a ideia de apresentar narrativas dramáticas e até mesmo melodramáticas a partir dos depoimentos pessoais dos não-atores convidados era defendida em cena, contra críticas que supostamente poderiam surgir em nome de um teatro "pós-dramático" ironicamente citado na peça.

${ }^{5}$ Ibidem, p. 11. Poderíamos citar ainda o trabalho da argentina Lola Arias, como a peça Campo Minado (apresentada na $5^{\mathrm{a}}$ MITsp, em 2018), em que a Guerra das Malvinas é tematizada a partir dos depoimentos dos não-atores argentinos e britânicos presentes em cena, ex-combatentes daquele conflito que apresentam suas visões pessoais sobre o episódio, "humanizando" a discussão política e substituindo uma visão histórica dos fatos pelas memórias individuais e repletas de afeto, chegando inclusive a pretender uma reconciliação emocionada - e politicamente bastante ingênua - entre os dois lados.

${ }^{6}$ FERNANDES, S. "Performatividade e Gênese da Cena". In: Revista de estudos da presença. Porto Alegre, v. 3, n. 2 (maio-agosto, 2013), p. 410.

${ }^{7}$ Ibidem.

${ }^{8}$ Ibidem, pp. 410-411.

${ }^{9}$ MENDES, J. G. "Teatros do real, teatros do outro: a construção de territórios da alteridade a partir da presença de não-atores em espetáculos contemporâneos”. In: Revista Sala Preta, v. 13, n. 2 (2013), p. 54.

${ }^{10}$ Pudemos assistir a apenas uma apresentação do espetáculo ao vivo, contando posteriormente, para nossa análise, com a dramaturgia do trabalho, gentilmente cedida pela atriz Maria Tendlau, e uma filmagem da encenação disponível online, em https://www.youtube.com/watch? v=R6HF_QP9Cdg .

${ }^{11}$ RANCIERE, J. Althusser's lesson. Op. cit., p. xvi.

${ }^{12}$ Texto gentilmente cedido pelo grupo, ver Tendlau, Maria. "Considerações acerca da violência na cena". In: Revista Sala Preta, v. 17, n. 1(2017), p. 262.

${ }^{13} \mathrm{O}$ artigo revisa o percurso do coletivo desde seu primeiro trabalho Guerra cega simplex feche os olhos e voe ou guerra malvada até Vergonha, passando por O que está aqui é o que sobrou (2012, adaptação do "Material Fatzer" de Brecht), para refletir sobre a presença da violência na cena teatral no contexto de uma discussão sobre a tensão entre representação e performatividade, ficção e real.

${ }^{14}$ Ibidem, p. 261.

15 Ibidem, p. 243.

${ }^{16}$ Ibidem, p. 260.

${ }^{17}$ É claro que não caberia aqui uma avaliação mais pormenorizada - e portanto mais justa - do longevo e relevante trabalho dessa companhia, a qual deveria levar em consideração diferentes tipos de experimentação empreendidos em diferentes momentos da sua trajetória. Para aprofundar um pouco mais essa discussão, remetemos ao nosso Da Teatrocracia: estética e política do teatro paulistano contemporâneo (São Paulo: Annablume, 2017), especialmente à Introdução, onde procuramos contextualizar a produção de teatro político em São Paulo desde os anos 90 . Notemos ainda que é a esse tipo de teatro e arte políticos que a epígrafe de Rancière para este ensaio se refere criticamente.

${ }^{18}$ Investigamos a impossibilidade dessa entrada do teatro documentário no campo da realidade, em detrimento da ficcionalização, em nosso primeiro artigo sobre o "Antiteatrodocumentário", em que analisávamos a peça Conversas com meu pai, de Janaína Leite e Alexandre Dal Farra (In: 
Revista Viso, n. 21 (jul-dez, 2017), pp. 28-47, disponível em: <http://www.revistaviso.com.br/visArtigo.asp?sArti=227>). Dal Farra também figura na ficha técnica de Vergonha, como "colaborador em dramaturgia", estando o "dramaturgismo" a cargo da atriz Maria Tendlau e do diretor Paulo Barcellos.

19 TENDLAU, M. Op. cit., pp. 260-261.

${ }^{20}$ Ibidem, p. 262.

${ }^{21}$ Yanet Aguilera, professora de História do Cinema, em conferência no dia 6 de setembro de 2017 por ocasião do "III Seminário de Estética e Crítica de Arte" do Departamento de Filosofia da FFLCH-USP, enfatizou o perigo de narcisismo (e consequente apagamento do outro) em que incorreria todo documentário como gênero (fílmico, no argumento dela, mas podemos pensar que também teatral) metalinguístico, autorreflexivo por excelência - autorreflexão correspondente a como a modernidade ocidental sempre se definiu em oposição ao seus "outros" atrasados.

22 ŽIŽEK, S. "Neighbours and Other Monsters: A Plea for Ethical Violence". In: REINHARD, K.; SANTNER, E. L.; ŽlŽEK, S. The Neighbor: Three Inquiries in Political Theology. Chicaco: The University of Chicago Press, 2005, p. 180.

${ }^{23}$ Ibidem, pp. 177-178.

${ }^{24}$ Ibidem, p. 178.

${ }^{25}$ RILKE, R. M. "Torso Arcaico de Apolo". In: BANDEIRA, M. Estrela da vida inteira. Rio de Janeiro: Nova Fronteira, 1993, p. 361.

${ }^{26}$ RANCIÈRE, J. A partilha do sensível: estética e política. São Paulo: Editora 34, 2005.

${ }^{27}$ Ibidem, pp. 262-263.

${ }^{28}$ ADORNO, T.; HORKHEIMER, M. Dialética do esclarecimento. Rio de Janeiro: Jorge Zahar, 2006, p. 187.

29 TENDLAU, M. Op. cit., p. 263.

${ }^{30}$ Ibidem, p. 247.

${ }^{31}$ RANCIERE, J. Le spectateur emancipé. Paris: La Fabrique, 2008, p. 85.

32 TENDLAU, M. Op. cit., p. 263.

${ }^{33}$ Ibidem.

${ }^{34}$ Ibidem.

${ }^{35}$. Ver Ibidem, pp. 264-265.

${ }^{36}$ Ibidem.

${ }^{37}$ RANCIERE, J. Le spectateur emancipé. Op. cit., p. 36.

${ }^{38}$ Ibidem, p. 266.

39 TIBURI, M. Ridículo político: uma investigação sobre o risível, a manipulação da imagem e o esteticamente correto. Rio de Janeiro: Record, 2017. (recurso eletrônico)

${ }^{40}$ Ibidem, p. 24.

${ }^{41}$ É complexa a relação entre a filosofia de Jacques Rancière e as diversas filosofias do reconhecimento que foram desenvolvidas contemporaneamente a ela. Pode interessar para nossa discussão o recente debate entre ele e Axel Honneth, principal responsável pela retomada do conceito de reconhecimento pela filosofia política atual (ver HONNETH, A.; e RANCIĖRE, J. Recognition or Disagreement: A Critical Encounter on the Politics of Freedom, Equality, and Identity. Nova York: Columbia University Press, 2016). 
42 Ibidem, p. 31.

${ }^{43}$ Ibidem, p. 27.

${ }^{44}$ COPJEC, J. "May '68, The Emotional Month”. In: ŽIŽEK, S. (org). Lacan: The Silent Partners. Londres: Verso, 2006, p. 90.

${ }^{45}$ Ibidem, p. 107, grifo nosso.

${ }^{46}$ Ibidem, p. 110.

47 É interessante notar que a crítica de Rancière tem sua origem no mesmo acontecimento histórico: o primeiro intelectual criticado por ele foi seu próprio mestre Louis Althusser, que se posicionou contra os estudantes. Isso poderia indicar uma oposição entre Rancière e Lacan, mas tentaremos antes encontrar aí uma produtiva relação de complementaridade dialética.

${ }^{48}$ LACAN, J. O seminário, Livro 17: O avesso da psicanálise (1969-1970). Rio de Janeiro: Jorge Zahar, 1992, p. 174.

49 Ibidem, p. 173.

${ }^{50}$ SARTRE, J.-P. O ser e o nada. Petrópolis: Vozes, 1997, p. 276.

${ }^{51}$ Agradecemos ao professor Vladimir Safatle por nos auxiliar com a compreensão da posição lacaniana.

52 DUNKER, C. Reinvenção da intimidade: políticas do sofrimento cotidiano. São Paulo: Ubu Editora, 2017.

${ }^{53}$ Ibidem.

${ }^{54}$ Ibidem, pp. 271-272.

${ }^{55}$ LACAN, J. Op. cit., p. 56.

${ }^{56}$ Ora, a autocrítica é uma das exigências mais repetidas pela esquerda neste momento pós-golpe (exigência normalmente marcada por um paradoxo: eu exijo dos outros essa ou aquela autocrítica).

${ }^{57}$ COPJEC,J. Op. cit., p. 91.

${ }^{58}$ TENDLAU, M. Op. cit., p. 265.

${ }^{59}$ Ibidem.

${ }^{60}$ A opção pela ficção pode ser justificada à medida que Copjec (Op. cit., p. 111) também opõe a vergonha à "paixão pelo Real" que Alain Badiou identificou "como um traço dominante do século passado", isso é, ao "desejo frenético de remover toda barreira que frustra nosso contato com o Real". Ora, não seria essa paixão que estaria por trás da obsessão fetichista da cena contemporânea pelo teatro documentário como exemplo dos "teatros do real"? Se "a paixão pelo Real trata toda superfície como um exterior a ser penetrado, uma barreira a ser transgredida ou um véu a ser removido", seria necessário "reconhecer nisso a lógica subjacente ao Discurso Universitário" e propor a vergonha como "uma 'barragem mental' contra o 'instinto agressivo' ou a paixão destrutiva pelo real", à medida que ela "não busca penetrar as superfícies ou arrancar os véus; antes, busca conforto neles, se esconde neles como um porto seguro" (Ibidem). Pois a vergonha não seria, segundo Copjec, "uma fuga fracassada do ser, mas uma fuga para o ser", para o ser "das superfícies, da existência social", a qual nos dá "a distância de nós mesmos e do nosso mundo que nos permite alterar ambos criativamente" (Ibidem).

61 Vale notar que o teatro documentário aqui avaliado como (melo)dramático não é o único existente, havendo também importantes experimentações da forma num sentido político, a partir das propostas das vanguardas alemãs e russas e sobretudo de Piscator, como hoje em São Paulo os trabalhos da Kiwi Companhia de Teatro - sendo a dissertação de mestrado da atriz do grupo 
Fernanda Azevedo um importante estudo sobre o assunto (AZEVEDO, F. A atualidade do teatro documentário: Percurso histórico e estudo do trabalho cênico Morro como um país. São Paulo, 2018. Dissertação de Mestrado. Instituto de Artes, Universidade Estadual Paulista).

62 TENDLAU, M. Op. cit..

${ }^{63}$ Ibidem.

${ }^{64}$ Ibidem.

${ }^{65}$ STIEGLER, B. Da miséria simbólica, vol. I: A era hiperindustrial. Lisboa: Orfeu Negro, 2018, pp. 32-33.

66 "Lacan compreendia perfeitamente que, se alguém entra em análise, é porque há uma suposição de saber sobre a verdade do seu desejo. Essa suposição de saber não é apenas uma curiosidade cognitiva, um querer se conhecer melhor, mas é uma expectativa de reconfiguração das estruturas da prática e do cuidado a partir de um saber sobre si mesmo. No entanto, esse saber suposto será destituído, não pela simples constatação da ignorância do analista ou pela ineficácia do discurso analítico, mas pela emergência da circulação de um objeto que sustentava a relação e que esteve, até então, velado. Isso nos explica por que, no discurso do analista, é o objeto que ocupa o lugar de agente. Nesse momento, revela-se ao sujeito como sua ligação à suposição de saber era, na verdade, um vínculo a um objeto que the causava, que lhe retirava de si. O saber analítico realiza-se ao se destituir". SAFATLE, V. "Lacan, revolução e liquidação da transferência: a destituição subjetiva como protocolo de emancipação política". In: Estudos Avançados, v. 31, n. 91 (set-dez, 2017), p. 213. Notemos a proximidade em relação à posição de Rancière (contra Althusser) mencionada acima. 